\title{
Heavy metal distribution in recent sediments along the Tietê River basin (São Pauro, Brazil)
}

\author{
Jefferson Mortatti,${ }^{1 *}$ Graziela Meneghel de Moraes ${ }^{1}$ and Jean-Luc Probst ${ }^{2}$ \\ ${ }^{1}$ Centro de Energia Nuclear na Agricultura, Universidade de São Paulo, \\ Av. Centenário 303, CEP 13416-970, Piracicaba, SP, Brazil \\ ${ }^{2}$ INP, ENSAT, Ecolab, Av. Agrobiopole, BP 107, 31216 Castanet Tolosan, France
}

(Received March 31, 2011; Accepted September 22, 2011)

\begin{abstract}
The distribution of heavy metals in recent sediments deposited along the Tietê River, a highly polluted river in southeast region of Brazil was studied. Around the metropolitan area of São Paulo city ( 25 million people), the pollution is related to municipal wastes and industrial effluents with reinforced downstream by agricultural activities. The observed increase of heavy metal concentrations is particularly important for $\mathrm{Zn}$ in the upper basin and $\mathrm{Cu}, \mathrm{Co}$ and $\mathrm{Cr}$ at mouth. Geo-accumulation index calculation, related to the regional background, showed that the sediments along the basin are seriously polluted by heavy metals of anthropogenic origin, mainly $\mathrm{Cu}, \mathrm{Co}, \mathrm{Cr}$ and $\mathrm{Zn}$. Calculated index suggests medium to very strongly pollution.
\end{abstract}

Keywords: heavy metals, Tietê River, sediments, geo-accumulation index, pollution

\section{INTRODUCTION}

Heavy metals are considered one of the greatest threats to the human health, due to their toxic effects on the environment. They are present in various compartments (atmosphere, water, soil, sediments and living organisms) and their forms are controlled by physical and chemical conditions as well as by biological processes. Natural occurrence of heavy metals is related to distribution of clastic mineral detritus from soil, rock and volcanic eruptions (Sanei et al., 2001; Mortatti and Probst, 2010), and from anthropogenic activities related to agriculture, domestic sewage, industrial and other minor effluents (Gomez et al., 2007).

In aquatic environments, heavy metals are usually found under different chemical forms subject to precipitation, adsorption and solubilization reactions, mainly with the bottom and suspended particulate load (Sholkovitz, 1992; Mortatti et al., 2002). The main factors affecting the sorption mechanism of heavy metals in the sediment pore water include particle size, $\mathrm{pH}$, redox potential, organic matter and biological activity (Förstner and Wittmann, 1981).

*Corresponding author (e-mail: jmortatt@cena.usp.br) Copyright $@ 2012$ by The Geochemical Society of Japan.
Variations in the aquatic environmental conditions can produce a release of heavy metals from the sediment to the water resulting in an increase of their bioavailability and consequent toxicity (Young et al., 1987; Wen and Allen, 1999). This aspect can be further investigated when the samples are analyzed in recent sediments, allowing a detailed study of heavy metals in association with the bioavailable and residual fractions, involving materials of different origins. The distribution and quantification of heavy metals in river sediments are usually based on concentrations obtained from extraction procedures and compared with the natural background levels (Salomons and Förstner, 1984).

The Tietê River, with $900 \mathrm{~km}$ of extension, is the longest river of the southeast part of Brazil. Its drainage basin, with a population of nearly 25 million people, is important for food and energy production, with more than ten hydroelectric power plants along the main channel of the river and tributaries. Over the years, with the increased population and consequent development of industry and agriculture, the river water and sediment quality deteriorated. In recent years, attention has been focused to the problem of river pollution related to the presence of heavy metals in dissolved and particulate loads (Mortatti and Probst, 2010).

This paper aims to characterize the heavy metal distribution in the recent sediments along the Tietê River (from headwater to the mouth) and evaluate the degree of pollution in the river basin, considering a regional background level. 


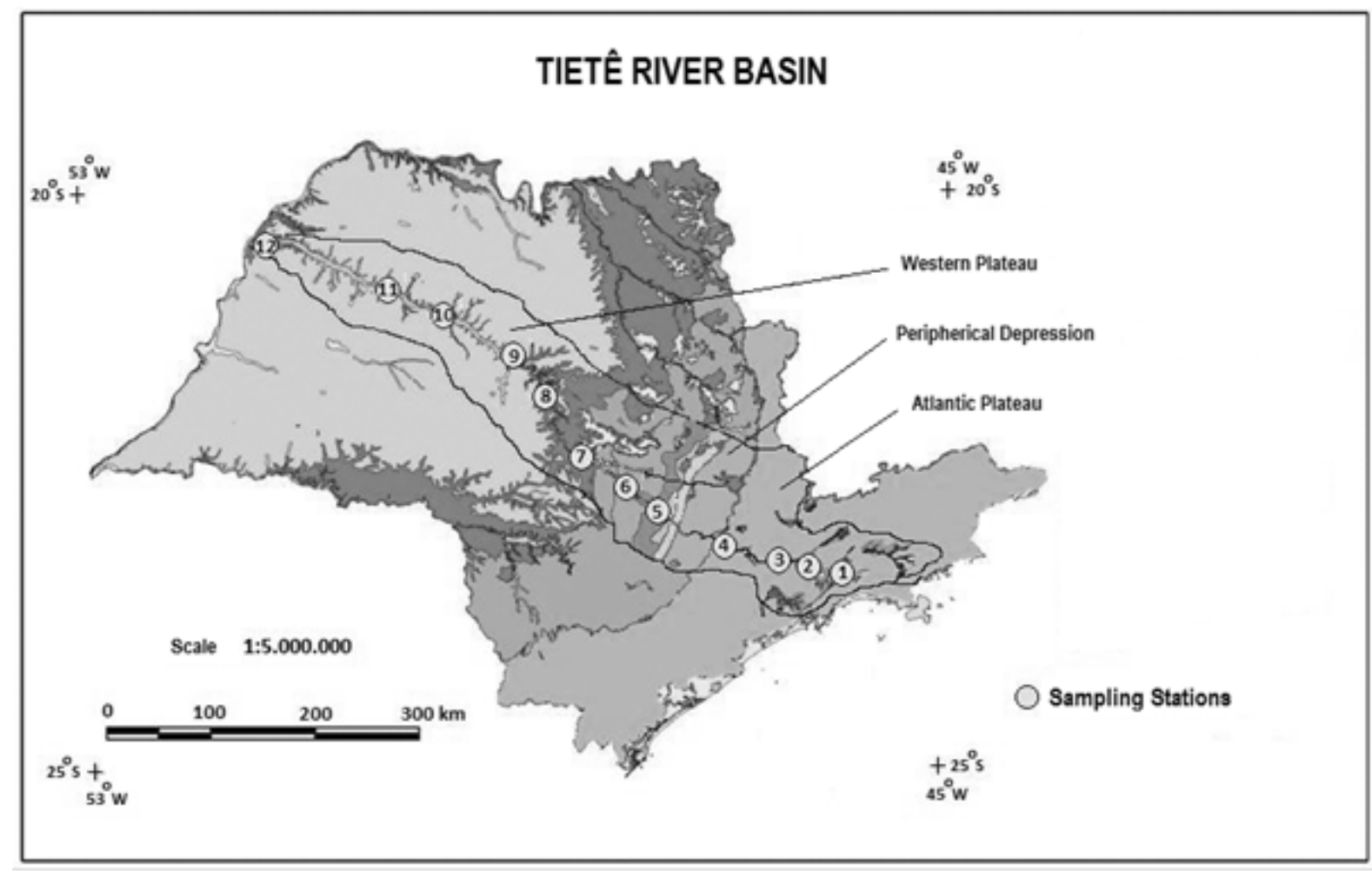

Fig. 1. Tietê River basin with the main morphological units and location of sampling sites: 1, Ponte Nova; 2, Biritiba; 3, Mogi das Cruzes; 4, Pirapora; 5, Tietê; 6, Anhembi; 7, Barra Bonita; 8, Bariri; 9, Ibitinga; 10, Promissão; 11, Nova Avanhandava; and 12, Três Irmãos. Total area refers to the Sao Paulo State, Brazil.

\section{STUdY AREA}

The drainage basin of the Tietê River covers 70,500 $\mathrm{km}^{2}$ and lies between latitude $24^{\circ} 10^{\prime} \mathrm{S}$ to $20^{\circ} 30^{\prime} \mathrm{N}$ and longitude $46^{\circ} 00^{\prime} \mathrm{E}$ to $51^{\circ} 30^{\prime} \mathrm{W}$. The river follows a southeast-northwest direction along the São Paulo state, the most industrialized state of Brazil, with about 62 cities, towards the Paraná River basin (Fig. 1). Along the main channel, the river flow is interrupted by several hydroelectric reservoirs to supply electric energy and drinking water.

The climate of the region is Cwa (Köppen classification), i.e., tropical rainy weather characterized by wet summer and dry winter; the mean temperature is $23.5^{\circ} \mathrm{C}$ and the mean annual rainfall has been $1,290 \mathrm{~mm}$ over the last 30 years.

According to Brasil (1983), the Tietê River basin is a sub-basin of the Paraná sedimentary basin and can be divided in three major morphostructural units: Atlantic Plateau (crystalline basement rocks) at the upper basin, Peripheral Depression and a transition zone (sedimentary rocks) at the middle of the basin and Western Plateau (Serra Geral and Bauru sedimentary formations).
In the upper basin, the Tietê River is severely polluted by domestic sewage and industrial effluents from the São Paulo metropolitan area. In the middle and lower Tietê basin, the anthropogenic influences are related to the agricultural practices (sugar cane plantation and pasture), domestic raw sewage and significant industrial activities.

\section{MATERIAL AND MethodS}

\section{Sampling procedure}

Twelve sediment cores of the riverbed were collected along the Tietê River basin in May 2009 by using a specially-designed gravity corer. Sampling was carried out during the middle falling stage of the river. Each core sampled in the middle part of main channel was representative of its corresponding location. A composite sample of recent sediments, corresponding to the first $5 \mathrm{~cm}$, was used for each station for calculating the heavy metal pollution degrees, whereas the deeper profiles (between 30 and $40 \mathrm{~cm}$ ) were used to determine the regional background. All sediment samples were air-dried and sieved $(63 \mu \mathrm{m})$ before the analytical procedures. 
Table 1. Total heavy metal concentration in recent sediments along the Tietê River

\begin{tabular}{lrrrrrrrrr}
\hline Station & $\mathrm{km}$ & $\mathrm{Cu}$ & $\mathrm{Co}$ & $\mathrm{Cr}$ & $\mathrm{Zn}$ & $\mathrm{Cd}$ & $\mathrm{Ni}$ & $\mathrm{Pb}$ & $\mathrm{Sc}$ \\
\cline { 2 - 10 } & & \multicolumn{7}{c}{$(\mathrm{mg} / \mathrm{kg})$} \\
\hline 1. Ponte Nova & 0 & 15.2 & 17.6 & 78.3 & 52.1 & 1.2 & 18.4 & 101.8 & 2.7 \\
2. Biritiba & 15 & 7.3 & 5.5 & 40.8 & 38.7 & 3.2 & 16.6 & 50.9 & 1.8 \\
3. Mogi & 30 & 33.6 & 21.9 & 251.8 & 201.6 & 5.1 & 29.6 & 110.6 & 6.1 \\
4. Pirapora & 115 & 202.1 & 26.8 & 126.8 & 421.3 & 5.6 & 72.0 & 67.3 & 8.9 \\
5. Tietê & 200 & 73.1 & 20.8 & 132.1 & 218.6 & 7.5 & 47.9 & 92.1 & 6.1 \\
6. Anhembi & 250 & 115.6 & 20.2 & 137.9 & 390.9 & 8.5 & 50.3 & 67.5 & 5.3 \\
7. Barra & 300 & 39.0 & 33.9 & 88.9 & 108.7 & 6.3 & 24.7 & 36.9 & 8.0 \\
8. Bariri & 350 & 76.4 & 61.2 & 151.8 & 107.1 & 6.3 & 41.0 & 63.6 & 7.7 \\
9. Ibitinga & 400 & 144.2 & 86.9 & 272.8 & 164.1 & 6.8 & 99.6 & 64.1 & 4.9 \\
10. Promissão & 500 & 56.5 & 35.9 & 241.9 & 57.9 & 5.4 & 69.4 & 53.9 & 4.9 \\
11. Avanhadava & 550 & 359.7 & 124.3 & 343.9 & 150.2 & 6.4 & 118.2 & 44.7 & 10.8 \\
12. Três Irmãos & 650 & 293.9 & 141.7 & 388.5 & 181.3 & 3.5 & 121.9 & 25.6 & 7.7 \\
\hline
\end{tabular}

\section{Extraction and analytical methods}

The heavy metals considered in this paper, $\mathrm{Cu}, \mathrm{Co}$, $\mathrm{Cr}, \mathrm{Zn}, \mathrm{Cd}, \mathrm{Ni}, \mathrm{Pb}$ and $\mathrm{Sc}$ were determined by ICP-OES, after complete dissolution by alkaline fusion (Samuel $e t$ al., 1985). Accuracy was controlled using Soil-7 standard (International Atomic Energy Agency-Reference materials). Differences between measured and certified values were generally below $5 \%$, except for $\mathrm{Cd}(9 \%)$.

\section{RESULTS}

Heavy metal content and downstream distribution patterns

Total heavy metal concentrations in recent sediments along the Tietê River are shown in Table 1.

The abundance order of heavy metal concentrations in recent sediments of the Tietê River basin were $\mathrm{Zn}>\mathrm{Cr}$ $>\mathrm{Pb}>\mathrm{Cu}>\mathrm{Ni}>\mathrm{Co}>>\mathrm{Cd}>\mathrm{Sc}$ for the headwater region (stations 1 to 4 ), $\mathrm{Zn}>\mathrm{Cr}>\mathrm{Cu}>\mathrm{Pb}>\mathrm{Ni}>\mathrm{Co}>>$ $\mathrm{Cd}>\mathrm{Sc}$ for the middle part of the basin (stations 5 to 7 ) and $\mathrm{Cr}>\mathrm{Cu}>\mathrm{Zn}>\mathrm{Ni}>\mathrm{Co}>\mathrm{Pb}>>\mathrm{Cd}>\mathrm{Sc}$ (stations 8 to 12) for the mouth. The highest concentration for $\mathrm{Zn}$ was obtained at Pirapora Station $(421.3 \mathrm{mg} / \mathrm{kg})$, just above the metropolitan area of São Paulo city, being charged by domestic sewage and industrial effluents. Similar values $(400.0 \mathrm{mg} / \mathrm{kg}$ ) were also observed by Silva et al. (2002) for the Billings reservoir near this upper station. In the mouth direction, highest $\mathrm{Cr}$ and $\mathrm{Cu}$ concentrations of 388.5 and $293.9 \mathrm{mg} / \mathrm{kg}$ were be verified respectively.

The heavy metal distributions in the recent sediments along the Tietê River main channel $(650 \mathrm{~km})$ were observed by plotting the metal concentrations against the distance (Fig. 2).

The distribution of $\mathrm{Cd}$ and Sc concentrations in recent sediments shows a small increase along the river, mainly at the middle part of the basin. In contrast, the distribution pattern of Co increases from the middle of the basin towards the mouth. Higher concentrations of $\mathrm{Zn}$ and $\mathrm{Pb}$ observed at upper stations 3 and 4 (Mogi das Cruzes and Pirapora) were related to the domestic sewage of the urban zone and at the middle part of the basin, stations 5 and 6 (Tietê and Anhembi) were associated with the sugarcane activities. After station 7 (Barra Bonita), the increase of $\mathrm{Cu}, \mathrm{Cr}$ and $\mathrm{Ni}$ concentrations coincides with the anthropogenic influences from agriculture to urban areas. Bevilacqua et al. (2009) at the middle part of the Tietê River basin observed a similar pattern. The case of $\mathrm{Cu}$ seems to be more serious, as it is used to control algae in hydroelectric reservoirs. Its concentration peak at station 11 (Avanhandava) was $359.7 \mathrm{mg} / \mathrm{kg}$. This occurrence is in agreement with Silvério (2003) who observed this behavior in the lower part of the basin.

\section{Regional background levels}

The natural background level for heavy metals in river sediments can be estimated in different ways. Martin and Meybeck (1979) proposed the use of heavy metal concentration values of average surface sediments, while Taylor and MacLennan (1995) suggested the use of the average abundance of these metals in the Earth crust. Turekian and Wedepohl (1961) suggested the use of sedimentary rocks and average shale metal compositions as comparative reference. However, it has been observed that these values adopted for heavy metals, vary globally and do not represent a more consistent study area. According to Silvério (2003), another criterion that might be adopted involves regional or local background levels, through the riverbed depth cores, if they have not been affected by anthropogenic action.

Use of regional or local background levels has been often discussed in literature involving heavy metal concentrations in soils, rocks and sediment profiles (Ferrand et al., 1999; Robaina et al., 2002; Marins et al., 2004; Rodrigues and Nalini, 2009). 


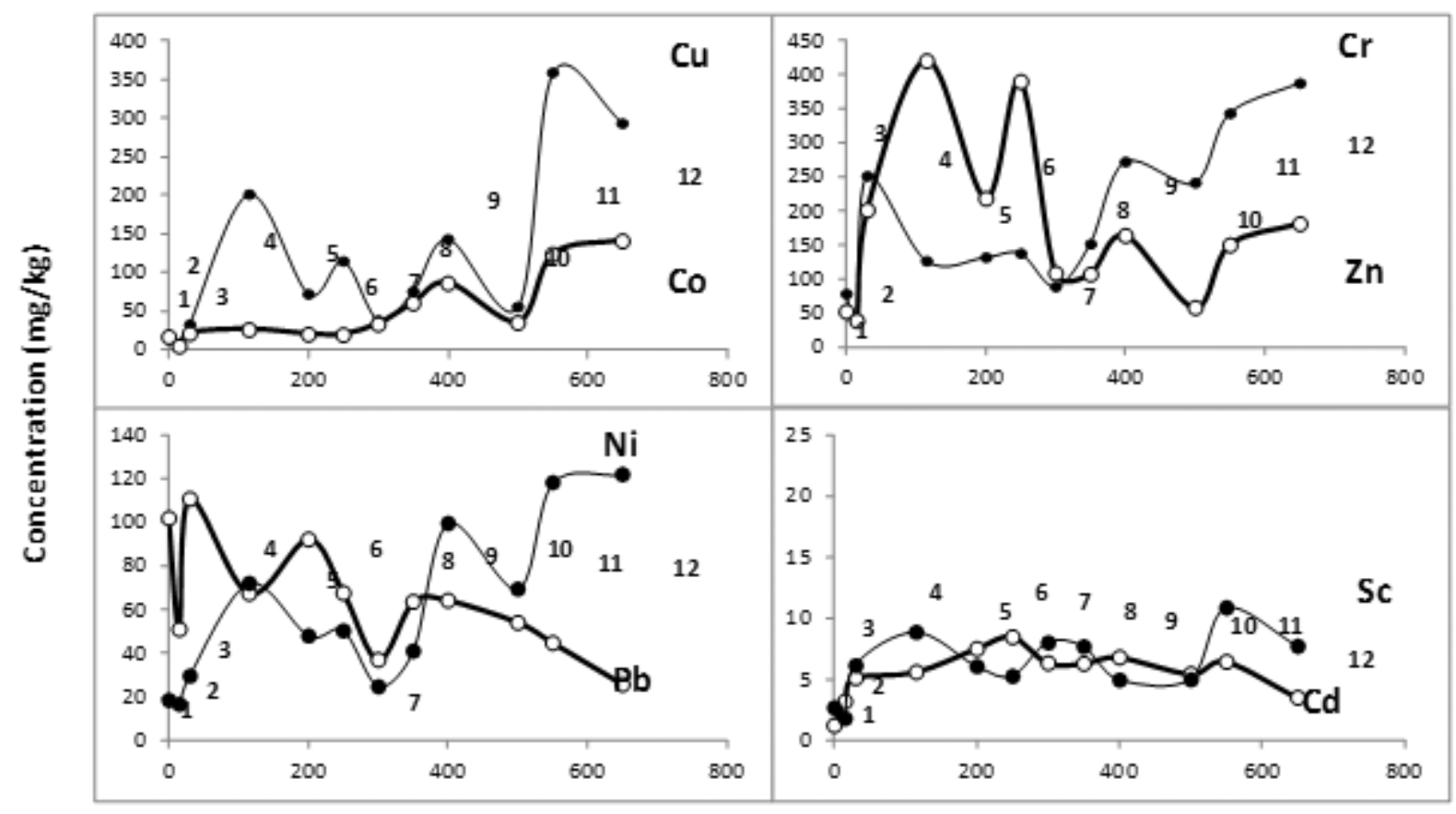

Downstream distance $(\mathrm{km})$

Fig. 2. Downstream distribution of heavy metal concentrations in recent sediments along the Tietê River.

Table 2. Regional background level of heavy metals for the Tietê River sediments, with respective standard deviation

\begin{tabular}{lrccccccc}
\hline Background & \multicolumn{1}{c}{$\mathrm{Cu}$} & $\mathrm{Co}$ & $\mathrm{Cr}$ & $\mathrm{Zn}$ & $\mathrm{Cd}$ & $\mathrm{Ni}$ & $\mathrm{Pb}$ \\
\cline { 2 - 8 } & & \multicolumn{7}{c}{ (mg/kg) } \\
\hline Upper & $5.1 \pm 0.3$ & $13.3 \pm 0.7$ & $60.4 \pm 3.2$ & $30.1 \pm 1.5$ & $2.1 \pm 0.2$ & $17.2 \pm 1.1$ & $50.2 \pm 4.0$ & $3.1 \pm 0.1$ \\
Middle & $14.2 \pm 1.2$ & $12.0 \pm 1.1$ & $40.3 \pm 2.7$ & $40.2 \pm 2.9$ & $4.0 \pm 0.3$ & $27.6 \pm 1.8$ & $48.1 \pm 3.7$ & $5.0 \pm 0.2$ \\
Lower & $30.1 \pm 2.8$ & $20.2 \pm 2.0$ & $50.5 \pm 4.1$ & $50.1 \pm 3.7$ & $4.0 \pm 0.2$ & $60.4 \pm 3.9$ & $40.3 \pm 2.6$ & $6.0 \pm 0.4$ \\
\hline
\end{tabular}

In this paper, the regional background levels for the heavy metals studied, related to the profiles of deeper sediments $(30-40 \mathrm{~cm})$ were determined in the upper (four stations), middle (three stations) and lower (five stations) parts of the drainage basin, in order to avoid spatial influences (Table 2).

\section{Intensity of heavy metal pollution}

The geo-accumulation index was used to evaluate the degree of heavy metal pollution in the riverbed recent sediments along the Tietê River basin during the sampling period. The geo-accumulation index (Igeo), introduced by Müller (1979), is derived as:

$$
\text { Igeo }=\log _{2}[\mathrm{M}]_{\text {sed }} / 1.5[\mathrm{M}]_{\text {background }}
$$

where $[\mathrm{M}]_{\text {sed }}$ is the concentration of a given heavy metal and, $[\mathrm{M}]_{\text {background }}$ is the geochemical background value of the element in the reference site.

The index Igeo is associated with a qualitative scale of pollution intensity and is divided into 7 degrees, which reflects the conditions ranging from none to very strong pollution.

In order to compare the intensity of heavy metal pollution in recent sediments of Tietê River, with reference to regional background and to the Earth's crust content in surface horizons, the indices of calculated geoaccumulations (Igeo) of heavy metals in sediments were calculated (Fig. 3). According to these indices, the recent sediments at Pirapora site (upper basin, station 4) are "strongly" polluted by $\mathrm{Cu}$ and $\mathrm{Zn}$ with reference to the 


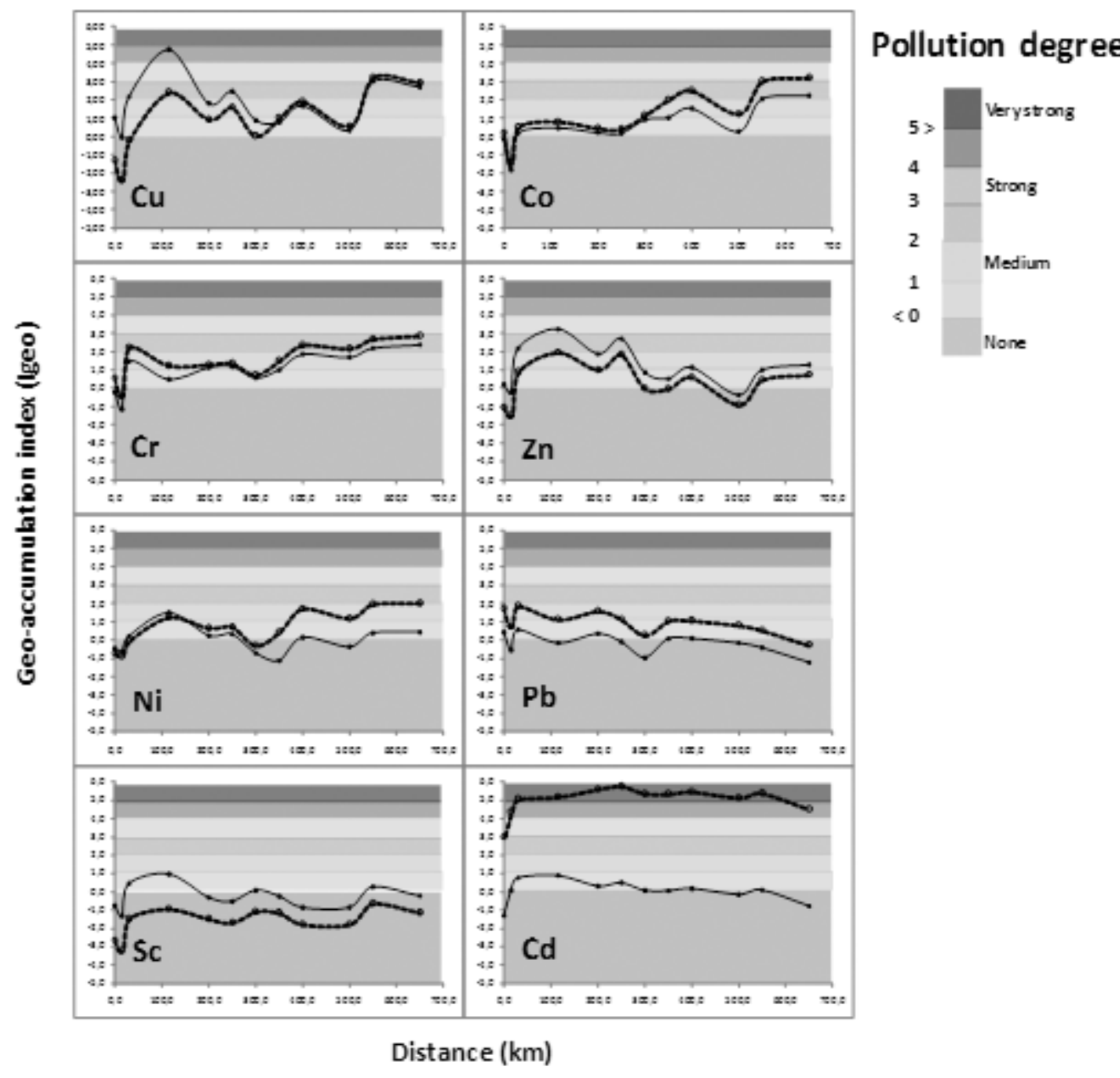

Fig. 3. Geo-accumulation index (Igeo) referred as pollution degree of heavy metal in recent sediments along the Tietê River. The dotted lines correspond to the calculated Igeo with reference to the Earth's crust content in surface horizons and thin lines to the regional background.

regional background and, "strongly to very strongly" in relation with the Earth's crust. In the middle part of the basin, at Anhembi site (station 6), the sediments are classified in both references as "medium to strongly" polluted by $\mathrm{Cu}$ and $\mathrm{Zn}$, and less intense by $\mathrm{Cr}$. Downstream, at Avanhandava and Três Irmãos sites (stations 11 and 12 ), the sediments are "strongly polluted" by $\mathrm{Cu}$, "medium to strongly" polluted by $\mathrm{Co}$ and $\mathrm{Cr}$ and "medium polluted" by $\mathrm{Zn}$, in both references. However, for $\mathrm{Ni}$ and $\mathrm{Cd}$, the background related to the Earth's crust overestimates the pollution degrees, classifying these stations as "medium to strongly" and "very strongly" polluted respectively, in contrast that verified in terms of regional background, which shows "none" pollution.

Sources of heavy metals: lithogenic and anthropogenic contributions

Scandium was used as reference element in a first approach, despite the low spatial variability observed in recent sediments and in the regional backgrounds, to estimate the lithogenic and anthropogenic contributions of heavy metals in recent sediments along the Tietê River, according Shotyk et al. (2000), as follows:

$$
\begin{aligned}
& {[\mathrm{M}]_{\text {lithog }}=[\mathrm{Sc}]_{\mathrm{sed}} \cdot([\mathrm{M}] /[\mathrm{Sc}])_{\text {lithog }}} \\
& {[\mathrm{M}]_{\text {anthrop }}=[\mathrm{M}]_{\text {sed }}-[\mathrm{M}]_{\text {lithog }}}
\end{aligned}
$$

where $[\mathrm{Sc}]_{\text {sed }}$ corresponds to the concentration in the riverbed sediment $(\mathrm{mg} / \mathrm{kg}),([\mathrm{M}] /[\mathrm{Sc}])_{\text {lithog }}$ to the ratio of heavy metal and Sc the lithogenic regional reference and, $[\mathrm{M}]_{\text {sed }}$ to the heavy metal concentration in the riverbed sediment $(\mathrm{mg} / \mathrm{kg})$.

The results of the heavy metal anthropogenic contributions along the Tietê River recent sediments are shown in Table 3. At the upper part of the basin, the anthropo- 
Table 3. Heavy metal anthropogenic contributions in recent sediments along the Tietê River

\begin{tabular}{lrrrrrrrrr}
\hline Station & $\mathrm{km}$ & $\mathrm{Cu}$ & $\mathrm{Co}$ & $\mathrm{Cr}$ & $\mathrm{Zn}$ & $\mathrm{Cd}$ & $\mathrm{Ni}$ & $\mathrm{Pb}$ \\
\cline { 3 - 9 } & & \multicolumn{7}{c}{ (\% Anthropogenic) } \\
\hline 1. Ponte Nova & 0 & 70.6 & 33.8 & 31.5 & 48.6 & - & 17.6 & 56.1 \\
2. Biritiba & 15 & 58.5 & - & 11.4 & 53.2 & 62.1 & 38.2 & 40.8 \\
3. Mogi & 30 & 69.6 & - & 51.3 & 69.6 & 20.0 & - & 7.7 \\
4. Pirapora & 115 & 92.7 & - & - & 79.0 & - & 30.3 & - \\
5. Tietê & 200 & 76.8 & 30.0 & 63.3 & 77.8 & 35.3 & 31.8 & 36.9 \\
6. Anhembi & 250 & 87.3 & 37.6 & 69.5 & 89.2 & 50.2 & 43.5 & 25.2 \\
7. Barra & 300 & 42.6 & 43.4 & 28.0 & 41.1 & - & - & - \\
8. Bariri & 350 & 49.7 & 58.2 & 57.8 & 40.2 & 18.4 & - & 19.4 \\
9. Ibitinga & 400 & 82.8 & 81.0 & 84.9 & 74.9 & 51.4 & 50.3 & 48.5 \\
10. Promissão & 500 & 56.0 & 53.8 & 82.9 & 28.5 & 39.0 & 28.3 & 38.5 \\
11. Avanhadava & 550 & 84.9 & 70.9 & 73.7 & 39.8 & - & 8.2 & - \\
12. Três Irmãos & 650 & 86.9 & 81.9 & 83.4 & 64.5 & - & 36.7 & - \\
\hline
\end{tabular}

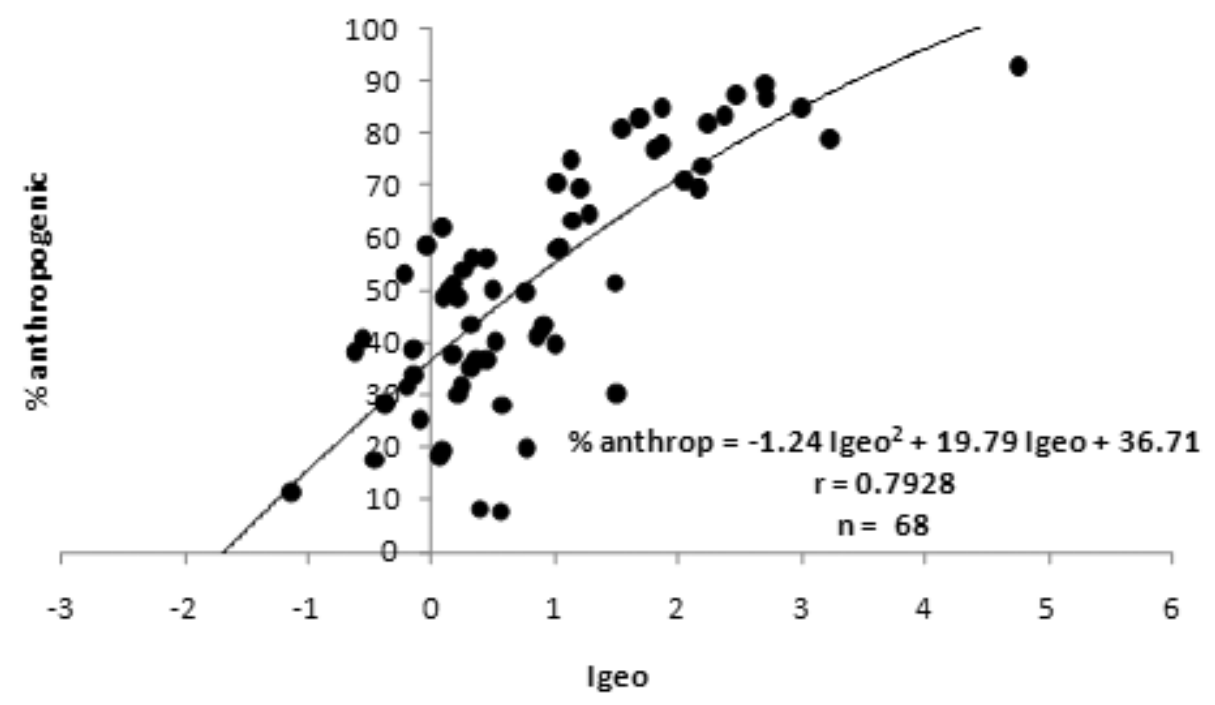

Fig. 4. Relationship between anthropogenic contribution and geo-accumulation index.

genic contribution of most of the investigated heavy metals revealed to be lower than the lithogenic contribution, with exception of $\mathrm{Cu}$ at Ponte Nova and Pirapora sites (stations 1 and 4 ) which was higher than $70 \%$ for anthropogenic origin. In contrast with the verified at the upper river, $\mathrm{Cu}, \mathrm{Cr}$ and $\mathrm{Zn}$ in the recent sediments at middle part of the basin showed to be of anthropogenic origin. The other heavy metals ( $\mathrm{Co}, \mathrm{Cd}, \mathrm{Ni}$ and $\mathrm{Pb}$ ) seem to be related to the lithogenic origin of the sampled sediments. The anthropogenic contributions, mainly for $\mathrm{Cu}, \mathrm{Co}$ and $\mathrm{Cr}$, increases downstream (stations 9 to 12) with values higher than $80 \%$.

These results reveal that the pollution from heavy metals in the recent sediments along the Tietê River is very serious, mainly for $\mathrm{Cu}$ and $\mathrm{Cr}$. $\mathrm{CuSO}_{4}$ is used to control algae production in hydroelectric reservoirs or derive from industrial effluents, while agrochemicals are the major sources of $\mathrm{Cr}$.

The indices of calculated geo-accumulation (Igeo) of heavy metals in the recent sediments along the Tietê River are strongly related to the anthropogenic contributions in the basin, as shown in Fig. 4. This significant relationship indicates anthropogenic influences in the whole Tietê River basin. The fitted polynomial model presents a theoretical minimum anthropogenic contribution (Igeo 1) to the heavy metal pollution in the recent sediments of around $50 \%$, which emphasizes the human activity in the drainage basin. 


\section{CONCLUSIONS}

This study highlights the heavy metal distribution in the recent sediments along the Tietê River in 12 sampling stations. The increase of heavy metal concentrations downstream reveals similar abundance order for the studied metallic species, particularly for $\mathrm{Zn}$ at the upper basin and $\mathrm{Cu}, \mathrm{Co}$ and $\mathrm{Cr}$ at mouth. The average concentrations of heavy metals were compared to the regional background in three sections of the basin. The index of geoaccumulation was used to evaluate the degree of heavy metal pollution of the Tietê River recent sediments and revealed that the sediments along the basin are seriously polluted by heavy metals of the anthropogenic origin, mainly for $\mathrm{Cu}, \mathrm{Co}, \mathrm{Cr}$ and $\mathrm{Zn}$. This result agrees with other researches in similar areas along the basin. Further research is needed to study heavy metal speciation and its effects in the living organisms.

Acknowledgments-This work was supported by Fundação de Amparo a Pesquisa do Estado de São Paulo, FAPESP, and Conselho Nacional de Desenvolvimento Científico e Tecnológico, CNPq.

\section{REFERENCES}

Bevilacqua, J. E., Silva, I. S., Lichtig, J. and Masini, J. C. (2009) Extração seletiva de metais pesados em sedimentos de fundo do Rio Tietê, São Paulo. Quím. Nova 32, 26-33.

Brasil. Ministério de Minas e Energia (1983) Projeto Radambrasil, folhas 23/24, Rio de Janeiro, 27-247 (Levantamento de Recursos Naturais, 32).

Ferrand, J. L., Hamelin, B. and Monaco, A. (1999) Isotopic tracing of anthropogenic $\mathrm{Pb}$ inventories and sedimentary fluxes in the Gulf of Lion (NW Mediterranean Sea). Cont. Shelf Res. 19, 23-47.

Förstner, U. and Wittmann, G. (1981) Metal Pollution in the Aquatic Environment. Springer-Verlag, 486 pp.

Gomez, A. A., Valenzuela, J. L. G., Aguayo, S. S., Meza, D. F., Ramirez, J. H. and Ochoa, G. O. (2007) Chemical partitioning of sediment contamination by heavy metals in the San Pedro River, Sonora, Mexico. Chem. Speciat. Bioavail. 19, 25-35.

Marins, R. V., Filho, F. J. P., Maia, S. R. R., Lacerda, L. D. and Marques, W. S. (2004) Distribuição de mercúrio total como indicador de poluição urbana e industrial na costa brasileira, Quím. Nova 27, 763-770.

Martin, J. M. and Meybeck, M. (1979) Elemental mass-balance of material carried by major world rivers. Mar. Chem. 7, 173-206.

Mortatti, J. and Probst, J. L. (2010) Characteristics of heavy metals and their evaluation in suspended sediments from
Piracicaba River basin (São Paulo, Brazil). Rev. Brasil. Geoc. 40, 375-379.

Mortatti, J., Bernardes, M. C., Probst, J. L. and Leleyter-Reinert, L. (2002) Composição química dos sedimentos fluviais em suspensão na bacia do rio Piracicaba: extração seletiva de elementos traço. Geochim. Brasil. 16, 123-141.

Müller, G. (1979) Schwermetalle in den Sedimenten des Rheinsveränderungen seit. Umschav. 79, 133-149.

Robaina, L. E., Formoso, M. L. L. and Pires, C. A. (2002) Metais pesados nos sedimentos de corrente como indicadores de risco ambiental-Vale do rio dos Sinos, RS. Rev. Inst. Geol. S. Paulo. 23, 35-47.

Rodrigues, A. S. L. and Nalini Junior, H. A. (2009) Valores de fundo geoquímico e suas implicações em estudos ambientais. Rev. Esc. Minas. 62, 155-165.

Salomons, W. and Förstner, U. (1984) Metals in the Hydrocycle. Springer-Verlag, Berlin, 349 pp.

Samuel, J., Rouault, R. and Besnus, Y. (1985) Analyse multieelementaire standardisée des matériaux géologique en spectrométrie d'émission par plasma a couplage inductif. Analusis. 13, 312-317.

Sanei, H., Goodarzi, F. and Van Der Flier-Keller, E. (2001) Historical variation of elements with respect to different geochemical fractions in recent sediments from Pigeon Lake, Alberta, Canada. J. Environ. Monit. 3, 27-36.

Sholkovitz, E. R. (1992) Chemical evolution of rare earth elements: fractionation between colloidal and solution phases of filtered river water. Earth Planet. Sci. Lett. 114, 77-84.

Shotyk, W., Blaser, P., Grüning, A. and Cheburkin, A. K. (2000) A new approach for quantifying cumulative, anthropogenic, atmospheric lead deposition using peat cores from bogs: $\mathrm{Pb}$ in eight Swiss peat bog profiles. Sci. Total Environ. 249, 281-295.

Silva, I. V., Abate, G., Lichtig, J. and Masini, J. C. (2002) Heavy metal distribution in recent sediments of the Tietê-Pinheiros river system in São Paulo State, Brazil. Appl. Geochem. 17, 105-116.

Silvério, P. F. (2003) Bases técnico-científicas para a derivação de valores-guia de qualidade de sedimentos para metais: experimento de campo e laboratório. Dr. Sci. Thesis, São Paulo University, 145 pp. (in Portuguese).

Taylor, S. R. and McLennan, S. M. (1995) The geochemical evolution of the continental crust. Rev. Geophys. 33, 241265.

Turekian, K. K. and Wedepohl, K. H. (1961) Distribution of the elements in some major units of the earth's crust. Geol. Soc. Amer. Bull. 72, 175-192.

Wen, X. and Allen, H. E. (1999) Mobilization of heavy metals from Le An River sediments. Sci. Total Environ. 227, 101108.

Young, T. C., De Pinto, J. V. and Kipp, T. W. (1987) Adsorption and desorption of $\mathrm{Zn}, \mathrm{Cu}$ and $\mathrm{Cr}$ by sediments from the Raisin River. J. Great Lakes Res. 18, 353-366. 